\section{Construction logistics in urban development projects - learning from, or repeating, past mistakes of city logistics?}

\author{
Mats Janné and Anna Fredriksson \\ Department of Science and Technology, Linköping University, Linköping, Sweden
}

Drivers and challenges of CLC utilization

Received 1 October 2019 Revised 21 August 2020 12 February 2021 26 July 2021 3 September 2021

Abstract

Purpose - The construction industry is reluctant to utilize construction logistics centres (CLC). To understand why, the purpose of the study is to increase the understanding of drivers and challenges of CLC utilization. Design/methodology/approach - Adopting an activity-based cost methodology, nine construction projects' CLC utilization in a Swedish urban development project is analyzed for a time period of three years (2013-2016).

Findings - There is a difference between drivers and challenges for implementing and utilizing CLCs, which are often implemented to reduce third-party disturbances. The drivers to utilize a CLC, however, stem from achieving efficient logistics. The authors identify two different utilization strategies; the CLC is used either for just-in-time (JIT) deliveries or as a consolidation point.

Research limitations/implications - The study shows that construction logistics is to some extent repeating some mistakes of its big brother, city logistics. The study hypothesizes that there are differences between CLC implementation and utilization drivers and challenges that are often overlooked, which can explain the lack of CLC utilization.

Practical implications - The study shows that it is crucial for construction projects to develop and formulate a logistics strategy for how to utilize the setup, i.e. deciding whether to use the setup as a consolidation point leading to fewer deliveries and more materials on-site, or as JIT, leading to more deliveries but fewer materials on-site.

Social implications - CLCs can reduce environmental impact and third-party disturbances. However, to make this come true, acceptance among the users is needed. The study provides understanding of drivers and barriers for CLC implementation and utilization that can increase acceptance among users (i.e. construction projects).

Originality/value - The current study is one of the first studies to analyze CLC utilization.

Keywords Construction logistics, Construction logistics centers, City logistics, Third-party logistics

Paper type Research paper

\section{Introduction}

With increased urbanization and densification, more materials and resources need to be transported to and from urban construction projects (Guerlain et al., 2019). Thus, the

(C) Mats Janné and Anna Fredriksson. Published by Emerald Publishing Limited. This article is published under the Creative Commons Attribution (CC BY 4.0) licence. Anyone may reproduce, distribute, translate and create derivative works of this article (for both commercial and non-commercial purposes), subject to full attribution to the original publication and authors. The full terms of this licence may be seen at http://creativecommons.org/licences/by/4.0/legalcode

The authors would like to extend their gratitude to all the company and municipal representatives who have participated in this study. Furthermore, the authors would like to thank the anonymous reviewers and the editor for their thorough work in reviewing the article; their work has increased the quality of the article substantially.

The research presented in this article has been financed by JPI Urban Europe/Sweden's Innovation Agency VINNOVA under Grant 2018-02499 and the Development Fund of the Swedish Construction Industry, SBUF, under Grant 13605.
Accepted 5 September 2021

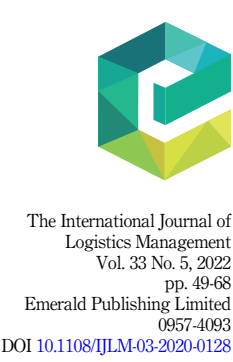


IJLM 33,5

importance of construction logistics in urban settings has increased. Guerlain et al. (2019) identify construction logistics as part of the city logistics realm, which, according to Strale (2019), includes research into urban freight transport as well as the policies, measures and initiatives imposed by municipalities, city authorities and private actors on the urban transport system. However, construction logistics is rarely managed as a part of city logistics initiatives; instead, construction logistics is treated as a special case of city logistics to be managed by the construction industry. Additionally, there has been limited knowledge transfer between the city logistics and construction logistics realms, meaning that construction logistics seems to be repeating the same mistakes as city logistics instead of learning from their experiences.

Construction projects need to focus on reducing their logistics impact on cities without sacrificing the efficiency of construction operations (Sundquist et al., 2018). Similarly to how urban consolidation centers (UCCs) are used in city logistics (Allen et al., 2014), one solution within construction logistics is to develop CLCs (Lundesjö, 2015). Like UCCs, CLCs focus on consolidating transports going into and out of construction sites, thus reducing disturbances to the surrounding community as well as improving logistics flows and planning opportunities for the construction project (Guerlain et al., 2019), which increases the projects' value-adding time (Spillane and Oyedele, 2017). However, Janné and Fredriksson (2019) found that the benefits of CLCs seem primarily to consist of reduced disturbances to the urban transport system and residents and businesses nearby. At the same time, the cost of utilizing CLC services has been found to be allocated predominantly to the construction projects (Hamzeh et al., 2007). Thus, there seems to be an imbalance between who incurs the costs and who reaps the benefits of employing CLCs. This imbalance, according to, Dubois et al. (2019), among others, has led to a situation where the construction industry is reluctant to utilize municipal or developer-implemented CLCs in their projects, as they see CLCs as added costs with little value. Studies within city logistics have shown that there are also utilization challenges connected to UCCs due to low commitment from end-users and service providers (Malhene et al., 2012), which depend on poor business models and a low focus on value-creation for end-users (Björklund et al., 2017). However, in construction logistics, the utilization challenges have not yet been thoroughly investigated. This makes it difficult to know if the challenges of increasing CLC utilization are real or if the low utilization is just an expression of construction projects' unrealized expectations or their lack of knowledge about how to reap the benefits of CLCs in their operations. Thus, the purpose of this study is to increase the understanding of drivers and challenges of CLC utilization.

This study takes the approach of exploring the utilization of drivers of and challenges to CLCs, through quantitatively studying CLC utilization in terms of space utilization, time for materials handling, number of deliveries and costs, with the help of invoices. It then compares the quantitative data with the qualitative understanding gathered through interviews and observations. The study is guided by the research questions as follows:

\section{$R Q 1$. How do construction projects utilize CLCs?}

RQ2. What are the drivers of and challenges to CLC utilization?

The paper is structured as follows: first, a literature review on city logistics and UCCs and construction logistics and CLCs is presented. This is followed by the research approach and methods used, including the development of the analysis method, alongside the case description. Thereafter, the findings are presented and analyzed in order to answer the research questions. This is followed by a discussion, and finally, the conclusions and contributions of the study are presented. 


\section{Literature review}

\section{City logistics and urban consolidation centers}

Even though city logistics has included initiatives like off-hour deliveries (Dablanc et al, 2013), it primarily promotes consolidation schemes such as UCCs (van Heeswijk et al., 2019). The goal of consolidation, according to Allen et al. (2014), is to achieve higher vehicle fill rates to reduce traffic volumes while maintaining goods volumes and reducing disturbances to the urban transport system. Consolidation schemes were often implemented as pilot or research projects, where funding was guaranteed for a limited time period (Vahrenkamp, 2016). However, as Van Duin et al. (2010), among others, show, achieving economic sustainability for UCCs has proven difficult. Once the funding was withdrawn, the UCC was decommissioned, and there are multiple examples of unsuccessful UCC schemes (Goldman and Gorham, 2006). Allen et al. (2012) found in their review that 50 of 114 reviewed schemes were still operational at the time of publishing. Vahrenkamp (2016), however, claims that 95\% of European UCC projects fail, citing among other sources, the European Union (EU) programs BESTUFS, BESTUFSII and SUGAR.

One of the problems encountered in UCC initiatives, according to Benjelloun et al. (2010), Crainic et al. (2009) and Björklund et al. (2017), is a lack of business models that consider economic longevity. Essentially, business models allow a company to design what activities to perform, how to perform them and how to create value for both the company and its customers (Sandberg et al., 2011). In order to decide on the business model, however, Sandberg et al. (2011) highlight three important questions need to be addressed: "Who is the customer?" "How do we make money in this business?" and "What does the customer value?" In city logistics and UCCs, these questions have rarely been addressed (Russo and Comi, 2020). Instead, the focus has primarily been on more technical aspects, such as designing distribution structures, vehicle types and reducing transports and emissions (Malhene et al., 2012), whereas a focus on value-creation has rarely been present (Björklund et al., 2017). This lack of focus on how to create value for and with customers, according to Verlinde et al. (2012), has also led to a lack of acceptance and utilization by customers, who do not see the added value, only added work tasks.

To increase UCC utilization, value-adding services were introduced. Aastrup et al. (2012) and Allen et al. (2014) categorize possible value-adding services for city logistics into off-site stockholding, inventory management/control, ordering processes, delivery help, consignment unpacking and preparation of products for display, return logistics, home deliveries/ast mile solutions and e-commerce collection and delivery points. By providing these services, the intention is to "do more" for customers by relieving them of these tasks. However, as discussed by Russo and Comi (2020), there has been little research on how these value-adding services have been utilized. There are exceptions; for instance, Gammelgaard et al. (2016) find that value-adding services are utilized in UCCs but also stress that these services are more likely to be utilized when co-created by the service provider and customer.

\section{Construction logistics}

The goal of any construction project is to deliver the project on time, on cost and meeting the stipulated quality. In order to do this so, a multitude of materials and resources need to be delivered on time, to the correct site and according to rules set by site management (Kim and Nguyen, 2018). However, the construction industry is characterized by one-off projects, needing to procure contractors, sub-contractors and suppliers for every new project (Seth et al. 2018). Navon and Berkovich (2005) argue that this temporary environment means that logistics is often overlooked or inadequately managed. According to Ying et al. (2018), logistics has traditionally been approached in an ad hoc manner by construction projects, which have solved their logistics needs on a day-to-day basis. Construction logistics has thus
Drivers and challenges of CLC utilization 
IJLM 33,5

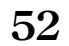

not been considered an opportunity (Ying et al., 2018), and several researchers have highlighted the potential for improving the construction industry's overall performance by improving its logistics management (Dubois et al., 2019).

Ghanem et al. (2018) divide the focus of construction logistics into two primary functions: the management of logistics activities on the construction site and the transport of resources and materials to and from the construction site. To ensure the efficiency of construction projects and their on-site operations, Ying et al. (2018) highlight the importance of managing on-site logistics activities such as planning, storage, materials tracking and waste management in order to facilitate a possible increase in the overall value-adding time of a project. This is elaborated by Thunberg et al. (2017) and Spillane and Oyedele (2017), who argue that construction logistics can be a catalyst for managing on-site issues such as too many materials on site and to enhance communication and collaboration among construction supply chain actors. Thunberg and Fredriksson (2018) argue that by coordinating different partners and tracking materials and resource needs through information technology (IT) systems, construction logistics can lead to more efficient construction projects. Actions to improve logistics are dedicated logistics coordination within the site organization (Sundquist et al., 2018) and logistics-based site-layout plans (Spillane and Oyedele, 2017) that clearly specify the material unloading zones and storage points (Lundesjö, 2015). Warehousing on or off site can also reduce the volume of materials on site and improve the overall materials control (Spillane and Oyedele, 2017). Using dedicated materials handlers can increase valueadding time for craftsmen and reduce accidents and risks on site (Sundquist et al., 2018).

The other important aspect of construction logistics is materials and resource deliveries to and from the site. Reports from Sweden, Belgium and Great Britain estimate that construction-related transport amounts to between 17 and $22 \%$ of urban freight transport (Department for Transport, 2017; Sveriges Byggindustrier, 2010; Strale et al., 2015), and Guerlain et al. (2019) even report that they can amount to as much as 30\% of urban freight transport. Therefore, the same demands from municipalities that are seen in city logistics (Dablanc et al., 2013) apply to construction logistics. Deliveries to and retrievals from construction sites need to be coordinated and managed in a way that reduces their impact on the urban transport system (Guerlain et al., 2019) while ensuring that construction can proceed without reduced efficiency on site due to missed or delayed materials deliveries (Dubois et al., 2019). One way to manage off-site construction logistics is through CLCs (Guerlain et al., 2019).

Construction logistics centers. According to Allen et al. (2014), the CLC is a construction industry adaptation of the UCC. While a normal UCC primarily targets smaller goods (Aastrup et al., 2012), that is not the case for the CLC. Construction materials are predominantly large (Ying et al., 2018), but they can also include smaller parcel deliveries. According to Lundesjo (2015), this implies that CLCs need to cater for a wide range of goods sizes and material types.

Employing a CLC means adding a new node into the delivery flow. Within this new node, additional activities will be performed. Based on the findings of Hamzeh et al. (2007) and Lundesjö (2015), four delivery sub-processes can be identified for a CLC setup (see Figure 1): (1) direct delivery to site; (2) delivery to CLC; (3) operations within CLC and (4) transport from CLC to site. If specified load-factor conditions are met, Lundesjö (2015) argues that direct deliveries can be used to feed construction sites. Similarly to the UCC case, some material flows achieve a high fill rate or are of a nature where consolidation is not possible, e.g. steel, concrete and large-volume elements. In these cases, it is inefficient to reroute deliveries through the CLC for additional handling and delayed delivery times (Lundesjö, 2015).

If routed via a CLC, the delivery sub-process operations within CLC (3) becomes part of the delivery process. In the CLC, materials are received, controlled, registered and at times put away for storage at the CLC (Lundesjö, 2015). Compared to direct deliveries, these are 


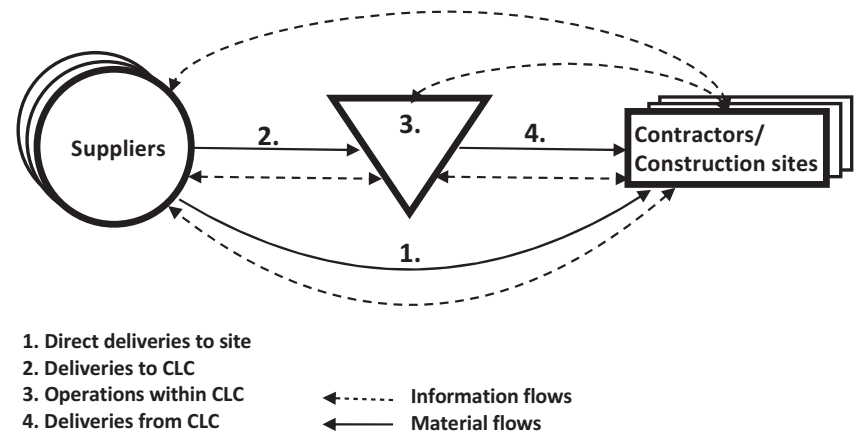

Drivers and challenges of CLC utilization

additional materials handling activities that add both time and costs to the delivery process (Abrahamsson and Aronsson, 2007). If requested, value-adding services such as storage, sequencing and kitting can be carried out before materials are sent onto site (Dubois $e$ t al., 2019). This means transferring activities from the on-site logistics to the off-site CLC. Additionally, Sundquist et al. (2018) argue that many of the logistics components described for on-site implementation can be offered as value-adding services through the CLC.

The final sub-process, transport from CLC to site (4), starts once the multiple deliveries are consolidated or materials are called off from a construction project (Hamzeh et al., 2007). As described by Lundesjö (2015), in this sub-process, materials are picked, packed and delivered through a milk run from the CLC. This again adds additional handling and transport activities to the delivery process and consequently also adds time and costs (Lundesjö, 2015).

\section{Comparing city logistics/UCCs and construction logistics/CLCs}

From the above literature review, it can be seen that both UCCs and CLCs aim to reduce the impact of transport on the urban environment through the consolidation of deliveries (Dablanc et al., 2013; Sundquist et al., 2018) while ensuring that materials and/or goods are delivered on time and to the correct recipients (Allen et al., 2014; Ghanem et al., 2018). Furthermore, both types of initiatives face the same challenges regarding utilization by the end-users, i.e. shop-owners in the city logistics/UCC case and contractors in the construction logistics/CLC case are not utilizing the initiatives to a sufficient extent. Largely, this seems to be because that the services provided have not been developed from a user perspective. The drivers and challenges for UCCs and CLCs are summarized in Table 1.

\section{Research approach and methods}

To increase the understanding of the utilization drivers of and challenges to a CLC, this study adopts a case study research design, as this allows for an in-depth understanding of a phenomenon's underlying mechanisms (Yin, 2014). The studied case, Stockholm Royal Seaport (SRS) development project, is one of the largest and longest-running development projects in Sweden to utilize a CLC, making it an ideal source for analyzing CLC utilization.

In preliminary discussions with the CLC operator and municipal development area manager, it was found that there was an opportunity to analyze invoice data for nine residential projects completed during the time period 2013-2016. In line with Yin (2014), the authors thus opted for an embedded single-case research design to analyze multiple construction projects' utilization of the CLC within the SRS development project. The nine individual projects were found to have utilized the CLC to varying degrees, making them 


\section{IJLM 33,5}

\section{4}

Table 1.

Drivers and challenges of UCCs and CLCs

\begin{tabular}{|c|c|c|c|}
\hline & $\begin{array}{l}\text { Identified drivers and } \\
\text { challenges }\end{array}$ & $\begin{array}{l}\text { Main source (city logistics or } \\
\text { construction logistics literature) }\end{array}$ & References \\
\hline \multirow[t]{8}{*}{ Drivers } & $\begin{array}{l}\text { Reduce disturbances to third } \\
\text { parties }\end{array}$ & Shared & $\begin{array}{l}2,6,12,13,18,23,25, \\
26,27\end{array}$ \\
\hline & Reduce emissions & Shared & $\begin{array}{l}2,6,12,13,18,23,26, \\
27\end{array}$ \\
\hline & $\begin{array}{l}\text { Reduce traffic movements in } \\
\text { urban areas }\end{array}$ & Shared & $\begin{array}{l}1,3,6,12,13,18,19,23 \\
25,26,27\end{array}$ \\
\hline & $\begin{array}{l}\text { Increase attractiveness of } \\
\text { city }\end{array}$ & City logistics & 2,6 \\
\hline & $\begin{array}{l}\text { Reduce no. of deliveries to } \\
\text { recipient }\end{array}$ & City logistics & $4,10,12,13$ \\
\hline & $\begin{array}{l}\text { Reduce logistics activities on } \\
\text { site }\end{array}$ & Construction logistics & $18,20,23,24,25,27$ \\
\hline & Increase planning activities & Construction logistics & $18,19,20,21,22,26,27$ \\
\hline & $\begin{array}{l}\text { Improve logistics } \\
\text { coordination }\end{array}$ & Construction logistics & $\begin{array}{l}18,19,20,21,22,23 \\
26,27\end{array}$ \\
\hline \multirow[t]{9}{*}{ Challenges } & Viable business models & Shared & $9,10,11,16,19,26$ \\
\hline & Viable regulatory measures & Shared & $6,9,10,11,16,19,26$ \\
\hline & Economic sustainability & City logistics & $5,8,9,10,11,16$ \\
\hline & $\begin{array}{l}\text { Acceptance of new working } \\
\text { practices }\end{array}$ & Shared & $11,14,16,17,19,24,27$ \\
\hline & $\begin{array}{l}\text { End-user utilization of } \\
\text { initiative }\end{array}$ & Shared & $\begin{array}{l}7,11,14,15,17,18,23, \\
27\end{array}$ \\
\hline & $\begin{array}{l}\text { Added activities in the } \\
\text { delivery process }\end{array}$ & Construction logistics & $18,23,26,26,27$ \\
\hline & $\begin{array}{l}\text { Co-creating service offerings } \\
\text { with end-users }\end{array}$ & City logistics & $11,16,17$ \\
\hline & Cost of utilization & Construction logistics & $19,21,26$ \\
\hline & Benefit imbalance & Construction logistics & $18,20,26,27$ \\
\hline
\end{tabular}

Note(s): ${ }^{1}$ Strale (2019), ${ }^{2}$ Dablanc et al. (2013), ${ }^{3}$ van Heeswijk et al. (2019), ${ }^{4}$ Allen et al. (2014), ${ }^{5}$ Van Duin et al. (2010), ${ }^{6}$ Goldman and Gorham (2006), ${ }^{7}$ Allen et al. (2012), ${ }^{8}$ Vahrenkamp (2016), ${ }^{9}$ Benjelloun et al. (2010), ${ }^{10}$ Crainic et al. (2009), ${ }^{11}$ Björklund et al. (2017), ${ }^{12}$ Gammelgaard (2015), ${ }^{13}$ Malhene et al. (2012), ${ }^{14}$ Verlinde et al (2012), ${ }^{15}$ Aastrup et al. (2012), ${ }^{16}$ Russo and Comi (2020), ${ }^{17}$ Gammelgaard et al. (2016), ${ }^{18}$ Janné and Fredriksson (2019), ${ }^{19}$ Ghanem et al. (2018), ${ }^{20}$ Ying et al. (2018), ${ }^{21}$ Thunberg et al. (2017), ${ }^{22}$ Thunberg and Fredriksson (2018), ${ }^{23}$ Sundquist et al. (2018), ${ }^{24}$ Spillane and Oyedele (2017), ${ }^{25}$ Lundesjö (2015), ${ }^{26}$ Guerlain et al. (2019) and ${ }^{27}$ Dubois et al. (2019)

good sources for understanding what drivers and challenges exist for construction projects in utilizing joint construction logistics setups such as the CLC in SRS. Table 2 shows the nine individual projects' characteristics. These projects consisted of building between two and five apartment buildings, with one exception; P8 built 18 town houses. All projects were built by different developers and contractors, apart from projects 6 and 7 which were built by the same main contractor, but with different site organizations and sub-contractors. Each project had its own unloading zone on site, although they shared access routes to varying degrees, depending on their location within the SRS area. The nine construction projects were all finalized during the time period 2013-2016.

The use of historical data can harbor unknown reporting bias in the case of quantitative data, and details may be forgotten by respondents when interviewing for qualitative data. To ensure validity and reduce these biases, this study used multiple data collection methods (Yin, 2014), which are detailed in Table 3. Data were collected during the time period 20162019 through 18 semi-structured interviews with representatives from the municipality (the municipal development area manager), the CLC operator and the projects (developers and 


\begin{tabular}{|c|c|c|c|c|c|}
\hline Project & Timeframe & No. buildings & Project size & Logistics coordinator & Drivers and \\
\hline P1 & 32 months & 4 & $\mathrm{M} € 46.3$ & Yes & CLC utilization \\
\hline $\mathrm{P} 2$ & 33 months & 2 & $\mathrm{M} € 36.6$ & Yes & \\
\hline P3 & 30 months & 2 & $\mathrm{M} € 19.9$ & Site manager & \\
\hline $\mathrm{P} 4$ & 34 months & 2 & $M € 23.9$ & Site manager & \\
\hline P5 & 23 months & 2 & $\mathrm{M} € 17.3$ & Site manager & \\
\hline $\mathrm{P} 6$ & 30 months & 5 & $\mathrm{M} € 51.8$ & Own construction logistics setup & 55 \\
\hline P7 & 25 months & 2 & $\mathrm{M} € 17.9$ & Own construction logistics setup & \\
\hline P8 & 24 months & 18 town houses & $\mathrm{M} € 15.9$ & Site manager & Table \\
\hline P9 & 24 months & 3 & $M € 10.6$ & Site manager & Project characteristics \\
\hline
\end{tabular}

main contractors). The interviews ranged in length from one to three hours. Additional data sources were seven on-site and CLC observations and documentation such as CLC evaluation reports, price lists, invoice data for the period 2013-2016, project documents and site layout plans (see Table 3).

An interview guide was developed, which contains questions on the municipality's drivers for introducing the CLC and the functionality of the CLC, the individual projects' utilization of the $C L C$ alongside drivers for and challenges to utilize the CLC to inform the analysis and provide an understanding of the projects' approach to the CLC. Finally, the perceptions of the project managers, the municipal development area managers and the CLC operators of the CLCs' performance were gathered to compare with the quantitative data.

The data analysis consisted of within-case and cross-case analysis, searching for explanations for how CLC utilization differed between the projects, as well as pinpointing the drivers and challenges that existed for increasing the CLC utilization. To find these utilization drivers and challenges, the CLC utilization needed to be analyzed. This was achieved by analyzing the invoice data, using the activity-based costing $(\mathrm{ABC})$ working procedure (Kim et al., 2011). According to Gríful-Miquela (2001), ABC highlights the relationships between activities and resource consumption, by identifying the relevant logistics tasks and breaking them down into individual activities (Griful-Miquela, 2001). Kim (2017) argues that it is possible to use $\mathrm{ABC}$ to achieve a better understanding of logistics performance and utilization of logistics resources. The invoice data were analyzed from the different projects' utilization rate in terms of number of direct deliveries, number of deliveries to and from the CLC, handling time, handling cost and storage capacity utilization, i.e. the delivery activities identified in Figure 1. Building on the ABC approach presented by Kim (2017), the quantitative analysis followed the three steps as follows:

(1) Direct deliveries are calculated based on the number of gate openings at each project;

(2) To assess the consolidation effect of the CLC, the ratio of the measures no. deliveries to CLC and no. deliveries from CLC is calculated and

(3) To find the utilization of the CLC, handling time, handling cost and storage utilization at the CLC give an approximation of time, cost and space savings on site.

\section{Findings}

The urban development project

The first step in ensuring sufficient housing in Stockholm is the construction of SRS, where a former petrochemicals industrial area is being transformed into 12,000 new homes and 35,000 new workplaces. The total investment in this development project is approximately $€ 2.2 \mathrm{bn}$. The first phase started in 2011 and the final phase is scheduled to be finished by 2030. 
IJLM
33,5

56

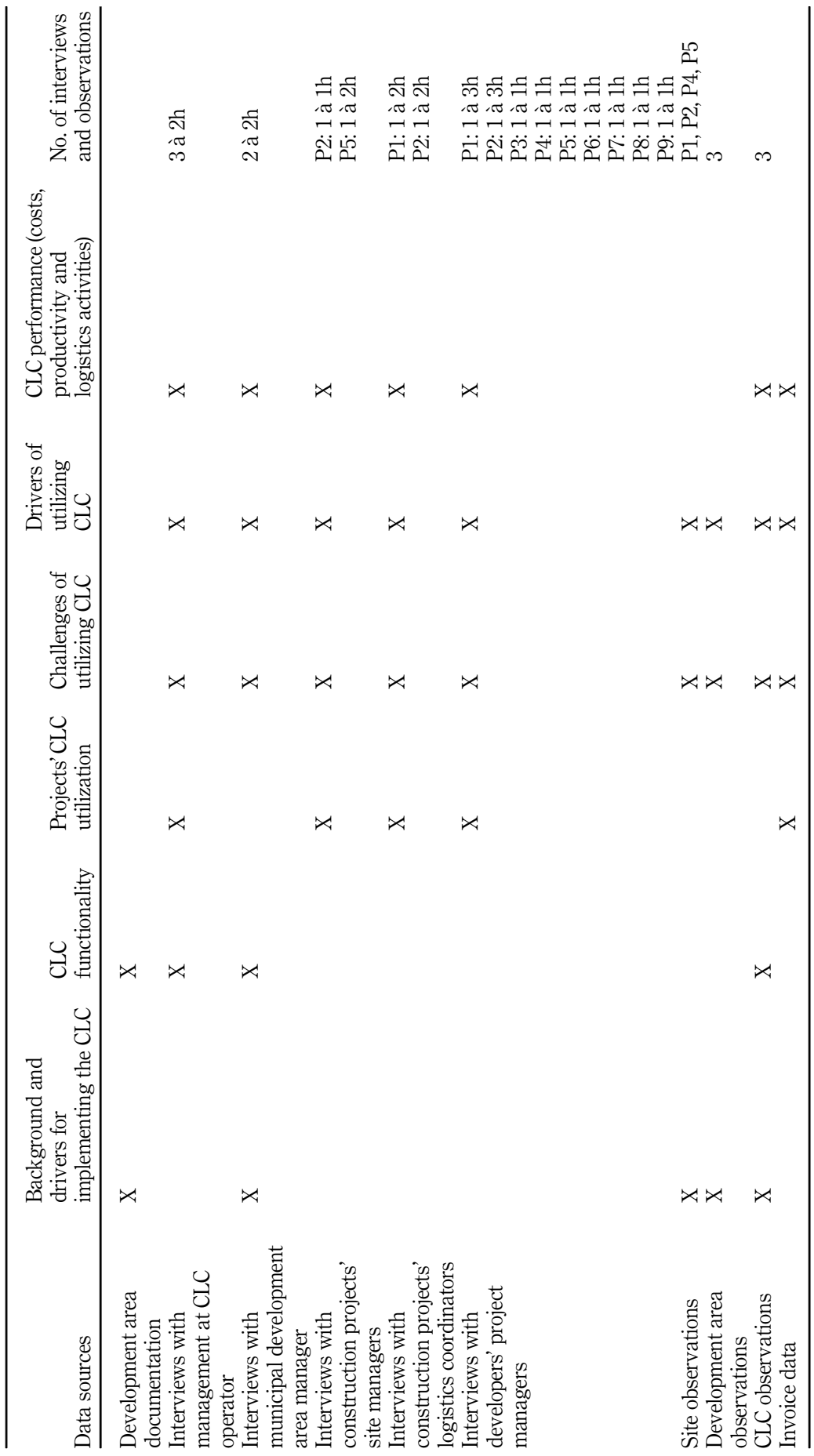

Table 3.

Data sources and areas of use 
While construction is ongoing in some phases, other areas will already have residents and companies in place.

Situated on the Baltic Sea shoreline and bordering the National City Park and the city center, the development area is limited in its access routes. As part of the Stockholm City Council's plan for a sustainable urban city, the SRS project is to be completed with minimum impact on the environment and surrounding residential and working areas. Accession to the CLC is mandatory for all projects in the SRS area, in accordance with the land allocation agreements with developers. The city has rules for how the CLC should be utilized by the projects, with the goal of minimizing construction freight transport in the SRS area and reducing disturbances to third parties in the vicinity.

\section{The CLC setup}

The SRS CLC is located close to the construction area and is based on a terminal and its operations, traffic piloting, education and perimeter fencing and security. The terminal structure comprises $2,200 \mathrm{~m}^{2}$ climate-controlled terminal tent, $230 \mathrm{~m}^{2}$ cold terminal tent, $1,000 \mathrm{~m}^{2}$ waste management area, $70 \mathrm{~m}^{2}$ office space and $3,000 \mathrm{~m}^{2}$ of outside space. The CLC is funded by a connection fee paid by developers as well as through service fees paid by the projects in SRS. Gate passing, for instance, is charged at a standard price of $€ 14$ per passage and the consolidated transport costs approximately $€ 107$ per hour. All services are stipulated in a price list available on the CLC's website. The services offered by the CLC are presented in Table 4. As it can be seen from the Table 4, all nine projects utilized the core services of the CLC to varying degrees. However, none of the projects opted for any of the value-adding services.

\section{Effects of utilizing CLCs in urban development projects}

Previous studies of the SRS CLC have shown that different actors have different opinions about its value. The municipality is content with the effect that the CLC has had on reducing urban traffic in the area, bringing it down by $60 \%$ (Bergman, 2016), whereas construction projects have experienced that the CLC adds costs but little value, leading to reluctance to engage and low utilization of its non-mandatory services (Janné and Fredriksson, 2019).

The introduction of a CLC into the delivery flow adds a number of activities within the sub-processes deliveries to CLC, operations CLC and deliveries from CLC (Figure 1). This section analyzes how these added activities have affected the construction projects in order to answer RQ1: "How do construction projects utilize CLCs?" Based on the CLC delivery process in Figure 1, this section is divided into two sub-sections analyzing delivery activities and CLC operations, respectively.

Comparing the sub-processes "direct deliveries" and "deliveries to and from the CLC". The construction projects focus on ensuring efficient construction operations and logistics activities on site. However, every time a delivery arrives, operations must be halted to receive the delivery, affecting the projects' operations. At first glance, fewer deliveries to site should thus be preferable for the construction projects. However, fewer deliveries to site also means that more materials need to be stored on site between deliveries, adding to on-site logistics activities such as materials relocation and adding risk elements in terms of clutter, risk of material thefts and wastage.

In the interviews, P1, P2, P6 and P7 all emphasized logistics as a prime concern when building in SRS and, to ensure that logistics would run smoothly, they developed logistics strategies and invested in the necessary logistics know-how. These projects all have on-site logistics coordinators or external construction logistics setups outside of the SRS (Table 2). Both P1 and P2 emphasized that they made sure to utilize the CLC as much as possible in order to learn how to work with construction logistics setups, whereas P6 and P7 combined
Drivers and challenges of CLC utilization

\section{洒}




\section{IJLM 33,5}

\begin{tabular}{l} 
Core services \\
\hline Traffic piloting \\
Short-term storage
\end{tabular}

Transport consolidation

Road maintenance

Return transport

Education

Joint site layout plans

Information to establishments

Perimeter fencing

Security and surveillance

Materials planning and ordering system
Table 4.

Services offered by the CLC

\section{Description}

Deliveries to the SRS area are given a time slot and gate code to pass through the gates into the development area. Each construction site has its own unloading area specified in the booking The CLC offers free short-term materials storage at the terminal for materials stored for less than a fortnight. If longer storage is needed, a fee is charged per square meter used and days stored Deliveries smaller than $€ 5$ pallets or $5 \mathrm{~m}^{3}$ must be consolidated before being delivered to the individual sites. This process adds another day to the overall delivery process

The CLC organization maintains the road network within the SRS area to ensure that the roads are accessible Return materials for shipment to the supplier or another chosen party are picked up as part of the CLC's milk round at construction sites. If needed, it is taken to short-term storage at the CLC or long-term storage at the terminal outside of Stockholm

Everyone who works within the SRS development area must undergo education on routines, rules and regulations before being allowed inside the perimeter fencing

The CLC is responsible for updating the area's site layout plans with the progress of the different projects and the current logistics plans

Information on the current state of affairs within the SRS area is distributed to a joint information channel in the projects' establishment sheds The CLC is responsible for ensuring that the development area is cordoned off and secure from trespassers. The perimeter fencing also includes the electronic gates for delivery vehicles and craftsmen

Security guards patrol the area and surveillance cameras ensure that the area is safe from thefts and vandalism Every transport must be booked into the joint CLC planning system a minimum of four days before delivery to SRS
Used by

Mandatory and used by all projects

Used by all projects

Used by all projects

Used by all projects

Mandatory and used by all projects

Used by all projects

Used by all projects

Used by all projects

Used by all projects

Mandatory and used by all projects 


\begin{tabular}{ll}
\hline Core services & Description \\
\hline Waste management & $\begin{array}{l}\text { The CLC manages all waste } \\
\text { management tasks such as collecting } \\
\text { fractions from site, compressing waste } \\
\text { centrally and ensuring that waste is } \\
\text { removed from the CLC to depot or } \\
\text { incineration }\end{array}$ \\
$\begin{array}{l}\text { The CLC operator ensures that the area } \\
\text { is clean of waste materials and litter. It } \\
\text { also ensures that any sanitation risks } \\
\text { are dealt with }\end{array}$
\end{tabular}

Value-adding services On-site materials handling

Logistics coordination

External long-term storage

Kitting

On-site waste management

Materials handling machinery and equipment

Specialty vehicles

Materials handling on site after working hours to ensure that construction materials are in the correct place when the working day starts

The CLC offers construction logistics coordinators who can help the projects with the coordination of logistics flows, conduct material flow analysis or attend coordination meetings

The CLC operator offers external warehousing outside of Stockholm for larger elements and materials

The CLC operator offers the manpower and time to perform some kitting of materials to have materials bundled for apartment, rooms, stairwells etc.

The CLC can provide operating disposal and sorting of construction waste at the site during construction, as well as waste containers ranging from 5 to $15 \mathrm{~m}^{3}$

If needed, unloading machinery can be booked through the CLC operator. This allows for shorter rentals than the traditional case

Specialty vehicles, such as crane trucks
Used by

Mandatory and used by all projects

Drivers and challenges of CLC utilization

Used by all projects or mobile cranes etc., can be booked through the CLC operator for shorter rentals than the traditional case
Managed by craftsmen within all projects

Managed internally by all projects, with dedicated logistics coordination in projects 1, 2, 6 and 7. Projects 3, 4, 5, 8 and 9 designated logistics coordination as the site managers' responsibility None. Instead, projects used the longterm storage at the CLC

\section{None}

Managed by the projects' site organization within all projects
None

None

Table 4.

the SRS CLC with their own construction logistics setup. These strategies imply that these four projects should be able to utilize the CLC and manage their logistics in SRS in a more efficient way, but can this be seen in the data? Projects P3, P4, P5, P8 and P9 on the other hand had not formulated logistics strategies for working in SRS.

To assess the impact the CLC has had on deliveries to sites, the consolidation effect, i.e. the ratio of number of incoming and outgoing deliveries to/from the CLC, is calculated. Table 5 below shows the consolidation effect for each of the nine construction projects. A negative number means fewer deliveries from the CLC than to the CLC, whereas a positive number means more deliveries from the CLC than to the CLC.

Overall, the transport reduction was primarily seen outside of the gates. As seen in Table 5, the overall delivery consolidation in the area is not translated into fewer deliveries to 


\begin{tabular}{|c|c|c|c|c|c|c|c|}
\hline $\begin{array}{l}\text { IJLM } \\
33,5\end{array}$ & Project & $\begin{array}{l}\text { No. direct } \\
\text { deliveries }\end{array}$ & $\begin{array}{l}\text { No. deliveries } \\
\text { to CLC }\end{array}$ & $\begin{array}{l}\text { No. deliveries } \\
\text { from CLC }\end{array}$ & $\begin{array}{c}\text { Total } \\
\text { deliveries to } \\
\text { site }\end{array}$ & $\begin{array}{c}\text { Consolidation } \\
\text { effect }(\%)\end{array}$ & $\begin{array}{l}\text { Logistics } \\
\text { strategy }\end{array}$ \\
\hline \multirow{5}{*}{60} & P1 & 6,539 & 136 & 146 & 6,685 & +7.4 & Yes \\
\hline & P2 & 7,473 & 280 & 177 & 7,650 & -36.8 & Yes \\
\hline & P3 & 2,602 & 41 & 70 & 2,672 & +70.7 & No \\
\hline & P4 & 1,268 & 67 & 118 & 1,386 & +76.1 & No \\
\hline & P5 & 2,508 & 176 & 114 & 2,622 & -35.3 & No \\
\hline & P6 & 7,083 & 277 & 266 & 7,349 & -4.0 & Yes \\
\hline Table 5. & P7 & 7,373 & 222 & 186 & 7,559 & -16.2 & Yes \\
\hline Consolidation effects & P8 & 3,743 & 72 & 94 & 3,837 & +30.6 & No \\
\hline of the CLC & P9 & 4,187 & 64 & 105 & 4,292 & +64.1 & No \\
\hline
\end{tabular}

individual construction sites. The difference in consolidation effect seen between the municipal development area manager $(60 \%)$ and the different project organizations is due to the effect of the milk-run deliveries. Project P1 experienced a reversed consolidation effect, i.e. they had more deliveries from the CLC to site than from supplier to the CLC $(+7.4 \%)$. This is counterintuitive to the consolidation idea, which is intended to reduce the number of deliveries to recipients by consolidating multiple suppliers' deliveries. However, this was part of P1's strategy; by using the CLC for short-term storage, P1 could call off materials as needed in a JIT manner. According to P1's logistics manager, this allowed for a less cluttered worksite, thus reducing the risk of material-related accidents.

At the other end of the spectrum, projects $\mathrm{P} 2, \mathrm{P} 6$ and $\mathrm{P} 7$ all achieved a reduction in the number of deliveries from CLC to site, compared to the number of deliveries from suppliers to CLC. For these projects, the consolidation effect ranges from a $4.1 \%$ to a $36.8 \%$ reduction in deliveries to site. What Table 5 also shows is that projects $\mathrm{P} 2, \mathrm{P} 6$ and $\mathrm{P} 7$ are the three projects with the most direct deliveries to site, 7, $473(\mathrm{P} 2), 7,083(\mathrm{P} 6)$ and 7, $373(\mathrm{P} 7)$, respectively. Thus, P2, P6 and P7 seem to have had similar strategies. P6 and P7 were built by the same main contractor, which utilizes its own consolidation construction logistics setup outside of SRS, by means of which consolidated JIT deliveries can be performed as direct deliveries. P2 on the other hand worked with its suppliers to coordinate JIT deliveries for reduced on-site storage, without compromising the fill-rate regulations of SRS. P2's project manager highlighted that this allowed for a more focused production process and that this was the aim of the project's strategy.

For the projects without a formulated logistics strategy (P3, P4, P5, P8 and P9), Table 5 shows that P3, P4, P8 and P9 saw reversed consolidation effects (of between $+30.6 \%$ and $+76.1 \%$ ), but it also shows that they had far fewer direct deliveries to site than the projects with a strategy. P5, for instance, experienced a reduction in deliveries from CLC to site $(-35.3 \%)$ and also had fewer direct deliveries. However, these five projects were smaller than three of the four with logistics strategies (P7 excluded) in terms of overall budget (see Table 2). Comparing P3, P4, P5, P8 and P9 to P7, however, we see that P7 has utilized the overall CLC setup more as part of its logistics strategy.

CLC operations. Routing deliveries through a CLC inevitably means that materials are handled more as goods are received, unloaded, stored, reloaded and delivered to site from the CLC. For these additional activities to add value to the delivery process, the added costs must be offset against efficiency gains. This is also evident in Table 6; materials handling time at the CLC for the projects with positive consolidation (P2, P5, P6 and P7) ranges from $813.56 \mathrm{~h}$ to $1907.74 \mathrm{~h}$, whereas the projects with a reversed consolidation effect have much lower materials handling times, ranging from $216.64 \mathrm{~h}(\mathrm{P} 3)$ to $521.25 \mathrm{~h}(\mathrm{P} 1)$. 


\begin{tabular}{|c|c|c|c|c|c|c|c|c|}
\hline Project & $\begin{array}{l}\text { Project } \\
\text { size }\end{array}$ & $\begin{array}{l}\text { Invoiced } \\
\text { CLC cost } \\
\text { for core } \\
\text { services }\end{array}$ & $\begin{array}{l}\text { CLC cost, } \\
\% \text { of } \\
\text { project } \\
\text { size }(\%)\end{array}$ & $\begin{array}{l}\text { Handling } \\
\text { time at } \\
\text { CLC }\end{array}$ & $\begin{array}{l}\text { Handling } \\
\text { cost }\end{array}$ & $\begin{array}{c}\text { Handling } \\
\text { cost, \% of } \\
\text { CLC } \operatorname{cost}(\%)\end{array}$ & $\begin{array}{l}\text { Storage } \\
\text { utilization }\end{array}$ & $\begin{array}{l}\text { Drivers and } \\
\text { challenges of } \\
\text { CLC utilization }\end{array}$ \\
\hline P1 & $\mathrm{M} € 46.3$ & $\mathrm{k} € 116.4$ & 0.25 & $521.25 \mathrm{~h}$ & $\mathrm{k} € 34.06$ & 29.3 & \multirow{9}{*}{$\begin{array}{c}20,644.77 \mathrm{~m}^{2} \\
15,505.04 \mathrm{~m}^{2} \\
7,266.97 \mathrm{~m}^{2} \\
12,808.47 \mathrm{~m}^{2} \\
8,466.4 \mathrm{~m}^{2} \\
43,145.67 \mathrm{~m}^{2} \\
25,352.27 \mathrm{~m}^{2} \\
12,443.38 \mathrm{~m}^{2} \\
8,990.51 \mathrm{~m}^{2}\end{array}$} & \\
\hline P2 & $\mathrm{M} € 36.6$ & $\mathrm{k} € 143.0$ & 0.39 & $813.56 \mathrm{~h}$ & $\mathrm{k} € 52.27$ & 36.6 & & \\
\hline P3 & $\mathrm{M} € 19.9$ & $\mathrm{k} € 56.0$ & 0.28 & $216.64 \mathrm{~h}$ & $\mathrm{k} € 13.71$ & 24.5 & & 61 \\
\hline P4 & $M € 23,9$ & $k € 38.6$ & 0.16 & $346.5 \mathrm{~h}$ & $\mathrm{k} € 21.89$ & 56.7 & & \\
\hline P5 & $M € 17.3$ & $\mathrm{k} € 85.8$ & 0.5 & $840.08 \mathrm{~h}$ & $\mathrm{k} € 54.15$ & 63.1 & & \\
\hline P6 & $\mathrm{M} € 51.8$ & $\mathrm{k} € 214.2$ & 0.41 & $1907.74 \mathrm{~h}$ & $\mathrm{k} € 123.78$ & 57.8 & & \\
\hline P7 & $\mathrm{M} € 17.9$ & $\mathrm{k} € 180.3$ & 1.01 & $1299.12 \mathrm{~h}$ & $\mathrm{k} € 85.13$ & 47.2 & & \\
\hline P8 & $\mathrm{M} € 15.9$ & $\mathrm{k} € 70.1$ & 0.44 & $329.88 \mathrm{~h}$ & $\mathrm{k} € 21.34$ & 30.4 & & Invoiced costs and \\
\hline P9 & $\mathrm{M} € 10.6$ & $\mathrm{k} € 70.1$ & 0.66 & $285.20 \mathrm{~h}$ & $18.05 \mathrm{k} €$ & 25.7 & & utilization of the $\mathrm{Cl}$ \\
\hline
\end{tabular}

Table 6 shows that the storage capacity has been utilized differently by the projects, ranging from $7266.97 \mathrm{~m}^{2}$ (P3) to $43,145.67 \mathrm{~m}^{2}$ (P6). These two projects approached consolidation in different ways, with P3 having the second highest reversed consolidation effect, while P6 had the smallest positive consolidation effect. According to P3's project manager, the project utilized the CLC's storage capacity to call off materials as needed throughout the project. P6, on the other hand, utilized the storage in combination with its own consolidation construction logistics setup outside of the SRS area, only routing larger materials, or shipments in need of storage nearby, to the SRS CLC.

Even though the construction projects within SRS have utilized the CLC to some extent, the interviews also revealed that the CLC was not used to its full potential by the construction projects. The CLC operator highlighted that none of the projects had utilized any of the valueadding and non-core services provided. Instead, the CLC has primarily been used as an offsite warehouse to reduce the on-site storage space required, or to buffer materials for delivery as needed, something that was highlighted as positive by P1 and P4. Partly this is due to the development project not allowing materials storage on site, thus forcing the construction projects to relocate their materials storage. This also means that the CLC has facilitated inventory management and materials traceability, which, according to P1 and P2, had the effect that materials handling operations on site were less time-consuming and less hazardous.

As can be seen in Table 6 , the cost of utilizing the CLC varies greatly among the projects, ranging from $0.16 \%(\mathrm{P} 4)$ to $1.01 \%(\mathrm{P} 7)$ of the total project size in $€$. However, the differences seen in CLC utilization between the projects with or without a logistics strategy (Table 5) cannot be translated into differences in CLC costs based on the current dataset.

\section{Drivers of and challenges to CLC utilization}

This section answers RQ2: "What are the drivers of and challenges to CLC utilization?"

The drivers and challenges for city logistics/UCCs and construction logistics/CLCs identified in the literature review (Table 1) were contrasted against the case study findings to investigate whether they could be verified as drivers and/or challenges in the SRS case or not. In the process of doing so, it was found that drivers and challenges can be observed at different levels, i.e. a driver might be for the overall area (e.g. reducing disturbances to third parties) or more specifically for individual projects (e.g. improving logistics coordination) or the operator (e.g. reducing the number of deliveries to recipients) or a combination of levels. This was evidenced by the different respondents in the case study, who described their reasoning behind utilizing the CLC, as well as the quantitative CLC utilization analysis (see Table 7). This distinction between different driver and challenge levels further led to the 
IJLM 33,5

\section{2}

identification of drivers and challenges being either of an implementation or utilization nature, meaning that more strategic drivers, such as reducing disturbances, emissions and traffic movements, are justifications for implementing a construction logistics setup but are not necessarily what drives the end users to utilize the setup. Instead, at a more operational level, the utilization drivers and challenges are connected to the projects' and operators' activities. Table 7 presents the drivers of and challenges to CLC utilization.

\section{Discussion}

The city logistics and construction logistics literature in Table 1 discusses the implementation of initiatives from a perspective of wanting to achieve an overall end-goal but do not distinguish between drivers and challenges for the implementation or utilization of UCCs or CLCs. However, from the case study, we can see that there is a difference between drivers and challenges for implementation and utilization. The case shows that the drivers for implementing CLCs stem primarily from a desire to reduce disturbances to the surrounding area or reduce environmental impact and traffic movements (cf. Dubois et al., 2019). These drivers are shared with city logistics initiatives ( $c f$. Gammelgaard, 2015), and the SRS case verifies them as drivers for implementing the CLC. The city logistics driver of increasing the attractiveness of the city (Goldman and Gorham, 2006) cannot, however, be verified in the SRS case, even though it could be argued that increasing the attractiveness of the city depends on the previous three drivers. The focus of these implementation drivers is purely to reduce the impact on society, whereas the drivers for utilizing a CLC must cater to end-users' needs.

Reducing the number of deliveries to recipients (Allen et al., 2014) and reducing logistics activities on site (Spillane and Oyedele, 2017) are end-user-focused utilization drivers. However, the SRS case highlights that these drivers are dependent on how the end-users choose to approach logistics in the construction project. In the SRS case, projects P1, P3, P4, P8 and P9 had more deliveries to site when utilizing the CLC (Table 5), but they also had the opportunity to plan for when they wanted those deliveries. Hence, they utilized the CLC to unburden their sites of some logistics activities. Thus, the drivers of reduced deliveries and logistics activities are semi-verified, meaning that they are important factors and services to offer even though they are not the main argument for all projects. Several respondents raised planning and coordination as crucial for working within the SRS area, thus verifying increasing planning activities (Thunberg and Fredriksson, 2018) and logistics coordination (Guerlain et al., 2019) as utilization drivers in the construction logistics case.

Additionally, four new CLC utilization drivers were seen in this study: reducing on-site storage, improving JIT call offs, improving the production process and increasing logistics know-how. The first three are closely linked to reduced on-site logistics activities but were explicitly mentioned by P1, P2 and P4 as goals for their CLC utilization. Many of the respondents said that construction logistics setups are becoming the norm in urban development projects, and P1 and P2 argued that utilizing the SRS CLC would enable them to learn how to utilize construction logistics setups and consider logistics in future projects.

When it comes to the challenges of increasing CLC utilization, the challenges viable business models and regulatory measures are verified. The SRS CLC and its regulations can be argued to have created value for the projects by relieving pressure on the site organizations in terms of logistics activities and increased safety. Similarly to UCCs, however, the CLC provided services based on the technical abilities of the operator (Malhene et al., 2012) and not on end-user utilization. None of the projects opted for any of the value-adding services. Thus, the CLC business model cannot be said to have been developed with end-users in focus (Sandberg et al., 2011). However, as described by Janné and Fredriksson (2019), the end-users were reluctant to use the CLC during the early stages of the SRS era. The question is thus 


\begin{tabular}{|c|c|c|c|c|c|c|}
\hline & $\begin{array}{l}\text { Identified drivers } \\
\text { and challenges }\end{array}$ & Main source & $\begin{array}{l}\text { Stockholm } \\
\text { Royal } \\
\text { Seaport }\end{array}$ & $\begin{array}{l}\text { General, } \\
\text { projects, } \\
\text { operator and/ } \\
\text { or area? }\end{array}$ & $\begin{array}{l}\text { Implementation } \\
\text { and/or utilization? } \\
\text { (I/U) }\end{array}$ & $\begin{array}{l}\text { Drivers and } \\
\text { challenges of } \\
\text { CLC utilization }\end{array}$ \\
\hline \multirow[t]{12}{*}{ Drivers } & $\begin{array}{l}\text { Reduce } \\
\text { disturbances to } \\
\text { third parties }\end{array}$ & Shared & Verified & Area & I & 63 \\
\hline & Reduce emissions & Shared & Verified & Area & I & \\
\hline & $\begin{array}{l}\text { Reduce traffic } \\
\text { movements in } \\
\text { urban area }\end{array}$ & Shared & Verified & Area & I & \\
\hline & $\begin{array}{l}\text { Increase } \\
\text { attractiveness of } \\
\text { city }\end{array}$ & City logistics & Not verified & - & I & \\
\hline & $\begin{array}{l}\text { Reduce no. of } \\
\text { deliveries to } \\
\text { recipient }\end{array}$ & City logistics & Semi-verified & $\begin{array}{l}\text { Area, } \\
\text { operator, P2, } \\
\text { P5, P6, P7 }\end{array}$ & $\mathrm{U}$ & \\
\hline & $\begin{array}{l}\text { Reduce logistics } \\
\text { activities on site }\end{array}$ & $\begin{array}{l}\text { Construction } \\
\text { logistics }\end{array}$ & Semi-verified & $\mathrm{P} 1, \mathrm{P} 2$ & $\mathrm{U}$ & \\
\hline & $\begin{array}{l}\text { Increase planning } \\
\text { activities }\end{array}$ & $\begin{array}{l}\text { Construction } \\
\text { logistics }\end{array}$ & Verified & $\begin{array}{l}\text { P1, P3, P4, P8, } \\
\text { P9 }\end{array}$ & $\mathrm{U}$ & \\
\hline & $\begin{array}{l}\text { Improve logistics } \\
\text { coordination }\end{array}$ & $\begin{array}{l}\text { Construction } \\
\text { logistics }\end{array}$ & Verified & P1, P2, P6, P7 & $\mathrm{U}$ & \\
\hline & $\begin{array}{l}\text { Reduce on-site } \\
\text { storage }\end{array}$ & Case findings & New & $\begin{array}{l}\text { P1, P2, P3, P4, } \\
\text { P6 }\end{array}$ & $\mathrm{U}$ & \\
\hline & Enable JIT call offs & Case findings & New & $\mathrm{P} 1, \mathrm{P} 2, \mathrm{P} 3, \mathrm{P} 4$ & $\mathrm{U}$ & \\
\hline & $\begin{array}{l}\text { Improve } \\
\text { production process }\end{array}$ & Case findings & New & $\mathrm{P} 1, \mathrm{P} 2, \mathrm{P} 4$ & $\mathrm{U}$ & \\
\hline & $\begin{array}{l}\text { Increase logistics } \\
\text { know-how }\end{array}$ & Case findings & New & P1, P2, P5 & $\mathrm{U}$ & \\
\hline \multirow[t]{10}{*}{ Challenges } & $\begin{array}{l}\text { Viable business } \\
\text { models }\end{array}$ & Shared & Verified & $\begin{array}{l}\text { Operator, P1- } \\
\text { P9 }\end{array}$ & $\mathrm{I} / \mathrm{U}$ & \\
\hline & $\begin{array}{l}\text { Viable regulatory } \\
\text { measures }\end{array}$ & Shared & Verified & $\begin{array}{l}\text { General, } \\
\text { operator, P5 }\end{array}$ & $\mathrm{U}$ & \\
\hline & $\begin{array}{l}\text { Economic } \\
\text { sustainability }\end{array}$ & City logistics & Not verified & - & I & \\
\hline & $\begin{array}{l}\text { Acceptance of new } \\
\text { working practices }\end{array}$ & Shared & Not verified & - & $\mathrm{U}$ & \\
\hline & $\begin{array}{l}\text { End-users' } \\
\text { utilization of } \\
\text { initiative }\end{array}$ & Shared & Verified & General & $\mathrm{U}$ & \\
\hline & $\begin{array}{l}\text { Added activities in } \\
\text { the delivery } \\
\text { process }\end{array}$ & $\begin{array}{l}\text { Construction } \\
\text { logistics }\end{array}$ & Verified & $\mathrm{P} 1-\mathrm{P} 9$ & $\mathrm{U}$ & \\
\hline & $\begin{array}{l}\text { Co-creating service } \\
\text { offerings with end- } \\
\text { users }\end{array}$ & City logistics & Semi-verified & $\mathrm{P} 1, \mathrm{P} 2$ & I & \\
\hline & Cost of utilization & $\begin{array}{l}\text { Construction } \\
\text { logistics }\end{array}$ & Verified & $\mathrm{P} 1-\mathrm{P} 9$ & $\mathrm{U}$ & \\
\hline & Benefit imbalance & $\begin{array}{l}\text { Construction } \\
\text { logistics }\end{array}$ & Verified & General & I & $\begin{array}{r}\text { Table } 7 \\
\text { Drivers of and }\end{array}$ \\
\hline & $\begin{array}{l}\text { Logistics know- } \\
\text { how }\end{array}$ & Case findings & New & P1, P2, P5 & $\mathrm{U}$ & $\begin{array}{l}\text { challenges to CLC } \\
\text { utilization }\end{array}$ \\
\hline
\end{tabular}


IJLM 33,5 whether the CLC would have been implemented at all had it been developed purely from an end-user perspective.

There were attempts at co-creating service offerings (Björklund et al., 2017) in SRS. P5 wanted a new gate into the development area; but due to the municipality's aim of reducing traffic in the area, this need could not be met. As such, this implementation challenge is semiverified in that the co-creation of services and value can be hindered by regulatory measures. This does not mean that it is impossible, however, as evidenced by P1 and P2 who, after discussions with the CLC operator, were allowed one gate code per week during excavation instead of one per passage.

In the SRS case, the utilization of the CLC is mandatory and, as the quantitative analysis shows, the CLC has been utilized (Table 5, Table 6). However, as the utilized services were all mandatory, the projects could not choose which services to use. Where the projects had a choice, i.e. the value-adding services, they did not utilize the services at all. This indicates that the mandatory element of large-scale construction logistics setups has a positive impact on service utilization but, given the choice, end-users are unlikely to utilize the services provided. The challenge of end-user utilization found in both city logistics (Verlinde et al., 2012) and construction logistics (Dubois et al., 2019) is thus verified.

The utilization challenge acceptance of new working practices found in both city logistics and construction logistics (Sundquist et al., 2018; Gammelgaard et al., 2016) is not verified in SRS. The projects in the SRS area have raised doubts regarding the regulations, and some attempts have been made to disregard the rules (Janné and Fredriksson, 2019), but on the whole the projects accepted the CLC because it helped to coordinate activities in SRS. One explanation for this acceptance lies in the temporary nature of construction (Seth et al., 2018), whereby new projects mean new conditions and supply chain partners. The construction industry is flexible in this sense and has a tradition of embracing the conditions of particular projects in order to be able to complete them.

The challenges added activities in the delivery process, cost of utilization and benefit imbalance are all verified (Ying et al., 2018). The case shows that there is a disconnection between the municipality's implementation goal of reducing disturbances and emissions and the construction management utilization goal of efficient construction projects. The effects of the CLC were primarily lower emissions, decreased risk of accidents and less congestion from fewer transports; yet, the cost of the CLC was carried by the construction projects. Even though all the projects utilized the CLC, they also reported that they felt the delivery process became more cumbersome due to the added activities such as additional material handling, joint planning, etc. The implementation challenge of economic sustainability found in city logistics (Russo and Comi, 2020) is not verified in the SRS case due to the CLC being mandatory, thus ensuring its longevity.

One new utilization challenge was found in the case study: logistics know-how. Just as logistics know-how was found to be a driver for utilizing the CLC, it can also be seen as a challenge if the project organizations lack or have low levels of logistics understanding and maturity. By its own admission, P5 was initially negative about the mandatory use of the CLC and came into the SRS area with little interest in logistics management. Thus, it did not start utilizing the CLC to a greater extent until the later stages of the project. In a sense, P5 also thus utilized the CLC as a learning opportunity for how to approach construction logistics in urban development projects.

\section{Conclusions and contributions}

The purpose of this study was to increase the understanding of drivers and challenges CLC utilization. This study is one of the first to elaborate on CLC utilization from a combined 
quantitative and qualitative perspective. Similar works have been conducted in city logistics, but this is the first study focusing on construction logistics.

This study contributes to research by strengthening the positioning of construction logistics as part of the city logistics realm. The study shows that, to some extent, construction logistics is repeating the mistakes of its big brother, city logistics, in that it has common utilization challenges and follows the same way of designing CLC setups based on implementation drivers. To a large extent, the sentiment in both literature and practice has been that, if there is a drive to implement a setup, the same drive applies to end-users utilizing it. However, this study contributes to the research by showing that there is a difference between implementation and utilization drivers and challenges. One must distinguish between implementation and utilization drivers and challenges because the implementation often stems from a goal of reducing disturbances to third parties, whereas the drive for utilizing a setup stems from a need to increase efficiency on site and reduce unnecessary logistics activities. A hypothesis for future research is that similar notions can be found in city logistics as well.

At a managerial level, this study has shown that construction projects can apply two possible strategies for utilizing a CLC. Either they use the CLC as a consolidation point to allow different suppliers' materials flows to be delivered as consolidated deliveries to the construction site or they can use the CLC as an external storage point to facilitate JIT deliveries to site. The former alternative is in line with the overall goal of the CLC, e.g. to consolidate deliveries, whereas the latter allows the construction projects to adjust their materials deliveries to the ever-changing production pace of the project. This leads to the second managerial contribution of this study: the projects that formulated a logistics strategy for working in SRS (P1, P2, P6 and P7) were found to utilize the CLC more as part of their operations than those that came into SRS without formulating a logistics strategy. It is thus important to note that when starting a construction project in an urban development area that has a construction logistics setup, part of the planning for that construction project must be to develop a strategy for how to work with that construction logistics setup.

This study contributes to society by its focus on reducing the disturbances and environmental impact from construction logistics. As discussed throughout the study, the implementation of large-scale construction logistics setups in urban development projects often stems from a vision of reducing the negative environmental impact and disturbances on third-parties. To achieve this vision, the end-users of the setup (the construction projects) need to be onboard and utilize the setup. However, as shown in this study, implementors and end-users often have conflicting CLC drivers. By highlighting the differences in implementation and utilization drivers, the study gives implementors and end-users a chance to achieve a joint understanding for the challenges and opportunities that the logistics setup brings. This can lead to a more holistic construction logistics setup implementation that is utilized by the end-users.

Limitations of the study are the following. We do not know how the utilization of a CLC has affected the on-site activities of the individual projects, i.e. what the actual cost, time and space effects have been on site. Further research thus needs to focus on in-depth studies of differences in on-site logistics depending on the use of construction logistics setups. Furthermore, this study is based on the delivery process of one CLC in the Swedish construction context. Other construction logistics setups are available and can lead to a whole range of other effects when utilized. Future research should investigate the drivers and challenges for implementing and utilizing other types of construction logistics setups and the effects of doing so, as well as comparing those findings to CLCs. The literature suggests that Europe has come a long way in researching CLCs and construction logistics setups, and future research should broaden the scope to other geographical contexts.
Drivers and challenges of CLC utilization 
IJLM
33,5

66

\section{References}

Aastrup, J., Gammelgaard, B. and Prockl, G. (2012), “3PL services in city logistics: a user's perspective", 24th Annual NOFOMA Conference, Naantali, Finland, 2012.

Abrahamsson, M. and Aronsson, H. (2007), "Measuring logistics structure", International Journal of Logistics Research and Applications, Vol. 2, pp. 263-284.

Allen, J., Browne, M., Woodburn, A. and Leonardi, J. (2012), "The role of urban consolidation centres in sustainable freight transport”, Transport Reviews, Vol. 32, pp. 473-490.

Allen, J., Browne, M., Woodburn, A. and Leonardi, J. (2014), "A review of urban consolidation centres in the supply chain based on a case study approach", Supply Chain Forum, Vol. 15, pp. 100-112.

Benjelloun, A., Crainic, T.G. and Bigras, Y. (2010), "Towards a taxonomy of City Logistics projects", Procedia - Social and Behavioral Sciences, Vol. 2, pp. 6217-6228.

Bergman, F. (2016), Bygglogistikcenter I Norra Djurgårdsstaden - Delavstämning, Exploateringskontoret, Stockholms stad, Stockholm.

Björklund, M., Abrahamsson, M. and Johansson, H. (2017), "Critical factors for viable business models for urban consolidation centres”, Research in Transportation Economics, Vol. 64, pp. 36-47.

Crainic, T.G., Ricciardi, N. and Storchi, G. (2009), "Models for evaluating and planning city logistics systems", Transportation Science, Vol. 43, pp. 432-454.

Dablanc, L., Giuliano, G., Holliday, K. and O'Brien, T. (2013), "Best practices in urban freight management", Transportation Research Record: Journal of the Transportation Research Board, Vol. 2379, pp. 29-38.

Department for Transport (2017), Freight Carbon Review, in Transport, D.f. (Ed.), Department for Transport (DfT), London.

Dubois, A., Hulthén, K. and Sundquist, V. (2019), "Organising logistics and transport activities in construction", The International Journal of Logistics Management, Vol. 30 No. 2, pp. 620-640.

Gammelgaard, B. (2015), “The emergence of city logistics: the case of Copenhagen's Citylogistik-kbh”, International Journal of Physical Distribution and Logistics Management, Vol. 45, pp. 333-351.

Gammelgaard, B., Andersen, C.B.G. and Aastrup, J. (2016), "Value Co-creation in the interface between city logistics provider and in-store processes", Transportation Research Procedia, Vol. 12, pp. 787-799.

Ghanem, M., Hamzeh, F., Seppänen, O. and Zankoul, E. (2018), “A new perspective of construction logistics and production control: an exploratory study", in González, V.A. (Ed.), 26th Annual Conference of the International Group for Lean Construction, Chennai, India, International Group for Lean Construction.

Goldman, T. and Gorham, R. (2006), "Sustainable urban transport: four innovative directions", Technology in Society, Vol. 28, pp. 261-273.

Gríful-Miquela, C. (2001), "Activity-based costing methodology for third-party logistics companies", International Advances in Economic Research, Vol. 7, pp. 133-146.

Guerlain, C., Renault, S. and Ferrero, F. (2019), "Understanding construction logistics in urban areas and lowering its environmental impact: a focus on construction consolidation centres", Sustainability, Vol. 11 No. 21, pp. 6118-6128.

Hamzeh, F.R., Tommelein, I.D., Ballard, G. and Kaminsky, P.M. (2007) "Logistics centers to support project-based production in the construction industry", in Pasquire, C.L. and Tzortzopoulos, P. (Eds), 15th Annual Conference of the International Group for Lean Construction, East Lansing, Michigan, USA.

Janné, M. and Fredriksson, A. (2019), "Construction logistics governing guidelines in urban development projects", Construction Innovation, Vol. 19, pp. 89-109.

Kim, Y.-W. (2017), Activity Based Costing for Construction Companies, John Wiley \& Sons, Oxford, ISBN: 9781119194675. 
Kim, S.-Y. and Nguyen, V.T. (2018), "A Structural model for the impact of supply chain relationship traits on project performance in construction", Production Planning and Control, Vol. 29, pp. 170-183.

Kim, Y.W., Han, S., Shin, S. and Choi, K. (2011), "A case study of activity-based costing in allocating rebar fabrication costs to projects", Construction Management and Economics, Vol. 29, pp. 449-461.

Lundesjö, G. (2015), “Consolidation centres in construction logistics”, in Lundesjö, G. (Ed.), Supply Chain Management and Logistics in Construction: Delivering Tomorrow's Built Environment, 1st ed., Kogan Page, London.

Malhene, N., Trentini, A., Marques, G. and Burlat, P. (2012), "Freight consolidation centers for urban logistics solutions: the key role of interoperability", IEEE International Conference on Digital Ecosystems and Technologies.

Navon, R. and Berkovich, O. (2005), "Development and on-site evaluation of an automated materials management and control model", Journal of Construction Engineering and Management, Vol. 131, pp. 1328-1336.

Russo, F. and Comi, A. (2020), "Investigating the effects of city logistics measures on the economy of the city", Sustainability, Vol. 12 No. 4, pp. 1439-1449.

Sandberg, E., Kihlén, T. and Abrahamsson, M. (2011), "Characteristics of a logistics-based business model", Journal of Marketing Channels, Vol. 18, pp. 123-145.

Seth, D., Nemani, V.S.R.K., Pokharel, S. and Al Sayed, A.Y. (2018), "Impact of competitive conditions on supplier evaluation: a construction supply chain case study", Production Planning and Control, Vol. 29, pp. 217-235.

Spillane, J.P. and Oyedele, L.O. (2017), "Effective material logistics in urban construction sites: a structural equation model", Construction Innovation, Vol. 17, pp. 406-428.

Strale, M. (2019), "Sustainable urban logistics: what are we talking about?", Transportation Research A: Policy and Practice, Vol. 130, pp. 745-751.

Strale, M., Lebeau, P., Wayens, B., Hubert, M. and Macharis, C. (2015), "Le transport de marchandises et la logistique à Bruxelles : état des lieux et perspectives", in Thiry, C. (Ed.), Cahiers de l'Observatoire de la mobilité de la Région de Bruxelles-Capitale, Bruxelles Mobilité, Brussels.

Sundquist, V., Gadde, L.-E. and Hulthén, K. (2018), "Reorganizing construction logistics for improved performance", Construction Management and Economics, Vol. 36, pp. 49-65.

Sveriges Byggindustrier (2010), Effektiva Byggtransporter, Sveriges Byggindustrier, Stockholm.

Thunberg, M. and Fredriksson, A. (2018), "Bringing planning back into the picture - how can supply chain planning aid in dealing with supply chain-related problems in construction?", Construction Management and Economics, Vol. 36 No. 8, pp. 425-442.

Thunberg, M., Rudberg, M. and Karrbom Gustavsson, T. (2017), "Categorising on-site problems: a supply chain management perspective on construction projects", Construction Innovation, Vol. 17, pp. 90-111.

Vahrenkamp, R. (2016), “25 years city logistic: why failed the urban consolidation centres?”, European Transport - Trasporti Europei, No. 60, paper \# 4.

Van Duin, J.H.R., Quak, H. and Muñuzuri, J. (2010), "New challenges for urban consolidation centres: a case study in the Hague", Procedia - Social and Behavioral Sciences, Vol. 2 No. 3, pp. 6177-6188.

van Heeswijk, W., Larsen, R. and Larsen, A. (2019), "An urban consolidation center in the city of Copenhagen: a simulation study”, International Journal of Sustainable Transportation, Vol. 13, pp. 675-691.

Verlinde, S., Macharis, C. and Witlox, F. (2012), "How to consolidate urban flows of goods without setting up an urban consolidation centre?”, Procedia - Social and Behavioral Sciences, Vol. 39, pp. 687-701.
Drivers and challenges of CLC utilization 
Yin, R.K. (2014), Case Study Research: Design and Methods, SAGE Publications, Thousand Oaks, CA.

Ying, F., Tookey, J. and Seadon, J. (2018), "Measuring the invisible: a key performance indicator for managing construction logistics performance", Benchmarking: An International Journal, Vol. 25, pp. 1921-1934.

\section{Corresponding author}

Mats Janné can be contacted at: mats.janne@liu.se

For instructions on how to order reprints of this article, please visit our website: www.emeraldgrouppublishing.com/licensing/reprints.htm Or contact us for further details: permissions@emeraldinsight.com 